\title{
ESCULTURAS DE BENITO DE HITA Y CASTILLO EN LA PARROQUIA DE LA CAMPANA (SEVILLA)
}

\section{BENITO DE HITA Y CASTILLO'S SCULPTURES IN THE PARISH OF LA CAMPANA (SEVILLE)}

\author{
José Roda PeÑa \\ Universidad de Sevilla, España \\ roda@us.es
}

En este artículo atribuimos al escultor Benito de Hita y Castillo (1714-1784) un conjunto de tallas en madera policromada, que se localiza en los dos retablos del crucero de la iglesia parroquial de santa María la Blanca, en la localidad sevillana de La Campana.

Palabras claves: Benito de Hita y Castillo, escultura barroca, siglo XVIII, La Campana, religiosidad popular.

In this article we attribute to the sculptor Benito de Hita y Castillo (1714-1784) a set of images in polychrome wood, that is located in the two altarpieces of the transept of the parish church of santa María la Blanca, in the sevillian town of La Campana.

Keywords: Benito de Hita y Castillo, baroque sculpture, 18th century, La Campana, popular religiousness.

El pasado año 2014, coincidiendo con el tercer centenario del nacimiento del escultor Benito de Hita y Castillo (1714-1784), se revisaron las principales aportaciones historiográficas que se habían vertido durante los últimos veinticinco años sobre tan destacada figura del barroco dieciochesco sevillano, al tiempo que se dio a conocer un significativo elenco de imágenes que podían atribuírsele con seguridad y se profundizó en la comprensión de los canales comerciales y los mecanismos sociales, culturales y religiosos que propiciaron el patrocinio artístico 
ejercido por la familia Massieu, cuyos integrantes, a través de intermediarios, le encargaron diversas esculturas para la isla canaria de La Palma ${ }^{1}$.

En esta ocasión, centraremos nuestra atención en un grupo de esculturas que hace escasos meses tuvimos la oportunidad de estudiar en la parroquia de santa María la Blanca de la villa de La Campana, en la campiña sevillana, cuya adscripción al catálogo de Benito de Hita y Castillo - que ahora proponemos por vez primera- nos parece del todo fiable, a pesar de que no se hallen documentadas, habiendo sido consideradas hasta el momento como obras anónimas.

En primer lugar, nos referiremos a la Inmaculada Concepción, de talla completa y tamaño ligeramente inferior al natural $(1,50 \mathrm{~m})^{2}$, que preside el retablo del lado de la epístola del crucero, en dicho templo parroquial. Se trata de una máquina lignaria que permanece sin dorar, acertadamente asignada por el profesor Recio Mir al entallador Tomás González Guisado "el Joven” hacia 1765, basándose en su similitud con los retablos colaterales de la iglesia de san Pedro de Carmona, labrados por aquél en torno a 1760-1764³. Desde luego, lo que sí es seguro es que este retablo de la Inmaculada estaba terminado antes de 1768, pues en una carta firmada en La Campana por el arquitecto Antonio de Figueroa el 15 de julio de ese año, afirma en referencia a este dispositivo que es "el mejor, el más moderno y de obra y labor más delicada"4. En verdad, merece gran estimación lo refinado de su talla y ornato rococó, así como la calidad de diseño de los cuatro sinuosos y casi desintegrados estípites que articulan en tres calles su cuerpo principal, donde apean sobre repisas las efigies de san Antonio de Padua y san Francisco Javier, también en blanco, puesto que la única imagen policromada del retablo es precisamente la de la Concepción.

No sabemos si tiene algún fundamento lo que comentara hace años un antiguo párroco y reafirmaran algunos feligreses, a propósito de que esta Inmaculada llegara a la iglesia a mediados del siglo XX, perdiéndose la pista de la que hasta

${ }^{1}$ RODA PEÑA, José: "Nuevas atribuciones al escultor Benito de Hita y Castillo en el tercer centenario de su nacimiento (1714-2014)", en Laboratorio de Arte, $\mathrm{n}^{\circ}$ 26, 2014, pp. 163-184; HERRERA GARCÍA, Francisco Javier: "Devoción, poder, comercio. Fundamentos ideológicos y recursos de don Felipe Massieu y Van Dalle como patrocinador artístico", en Anuario de Estudios Atlánticos, nº 60, 2014, pp. 357-411. Del mismo autor: "Escultura sevillana de la segunda mitad del XVIII: prejuicios, ideas teóricas y algunas atribuciones", en Archivo Hispalense n 294-296, 2014, pp. 269-293.

${ }^{2}$ Erróneamente fue conceptuada como una escultura "fechable en el siglo XVII" por MIRA CABALlOS, Esteban: La Campana. Noticias históricas. Sevilla: Muñoz Moya editor, 1998, p. 70.

3 RECIO MIR, Álvaro: "Retablo de la Inmaculada", en HALCÓN, Fátima; HERRERA, Francisco y RECIO, Álvaro: El retablo barroco sevillano. Sevilla: Universidad de Sevilla, Fundación El Monte, 2000, p. 397.

${ }^{4}$ MIRA CABALLOS, Esteban: La Campana. Noticias históricas, op. cit., p. 70. 
entonces estuviera aquí entronizada ${ }^{5}$, pero lo cierto es que, cronológica y estilísticamente, casa a la perfección con la ensambladura que la alberga, y hasta en el esplendente estofado de su túnica -blanca con las vueltas de las mangas en tonos cerúleos- y manto -azul con el envés rojo metálico- se desarrolla una profusión de rocallas que comulga con el pletórico adorno que se adueña del retablo, al igual que sucede con el modelo rococó de la corona de plata que luce la Virgen sobre su cabeza.

Ceán Bermúdez, en el brevísimo apunte biográfico que dedicó a Hita y Castillo, le concedía una "cierta gracia en las imágenes de la Virgen”, y esta escultura de la Inmaculada es, desde luego, buena prueba de su extensa y exitosa dedicación a diversas modalidades de la iconografía mariana, donde ocupa un lugar descollante la temática concepcionista, como vienen a demostrarlo la Purísima que tiene documentada en la capilla sacramental de la iglesia de santa Catalina $(1752-1753)^{7}$, aquella otra que, como cofrade que fue de la Hermandad Sacramental de la parroquia de santa Marina, donó a esta corporación eucarística en 1767, habiéndose perdido en el incendio perpetrado en dicho templo el 18 de julio de $1936^{8}$; y las que, por ejemplo, se le atribuyen en la parroquia de santa María Magdalena $^{9}$, en la basílica de María Auxiliadora ${ }^{10}$-todas ellas en Sevilla-y en un oratorio particular de La Orotava, en la isla de Tenerife (c. 1768) ${ }^{11}$.

Hita y Castillo, en la Inmaculada de la parroquia de La Campana, ha plasmado un rostro juvenil y de expresión encantadora, que en recatado gesto entorna

\section{${ }^{5}$ Ibídem.}

${ }^{6}$ CEÁN BERMÚDEZ, Juan Agustín: Diccionario histórico de los más ilustres profesores de las Bellas Artes en España. T. I. Madrid: Viuda de Ibarra, 1800, p. 289.

${ }^{7}$ GONZÁLEZ ISIDORO, José: Benito de Hita y Castillo (1714-1784). Escultor de las Hermandades de Sevilla. Sevilla: Caja de Ahorros Provincial San Fernando de Sevilla, 1986, p. 137. MORALES, Alfredo J.: "La capilla sacramental de Santa Catalina. Un espacio del barroco sevillano", en Capilla Sacramental de la Iglesia de Santa Catalina. Sevilla. Madrid: Fundación Argentaria, 1997, p. 31. ILLÁN, Magdalena y VALDIVIESO, Enrique: Noticias artísticas sevillanas del archivo Farfán Ramos. Siglos XVI XVII y XVIII. Sevilla: Guadalquivir Ediciones, 2005, p. 107.

${ }^{8}$ BERMÚDEZ REQUENA, Juan Manuel: "Consideraciones históricas sobre la Cofradía del Santísimo Sacramento de la iglesia de Santa Marina de Sevilla”, en IV Simposio sobre Hermandades de Sevilla y su provincia, Sevilla: Fundación Cruzcampo, 2003, p. 64.

${ }^{9}$ HERNÁNDEZ DÍAZ, José: "La Parroquia sevillana de Santa María Magdalena. Templo del extinguido Convento de Dominicos de San Pablo", en Boletín de Bellas Artes, $2^{a}$ época, ${ }^{\circ}$ VIII, 1980, p. 226. GONZÁLEZ ISIDORO, José: Benito de Hita y Castillo (1714-1784). Escultor de las Hermandades de Sevilla, op. cit., p. 148.

${ }^{10}$ RODA PEÑA, José: "Nuevas atribuciones al escultor Benito de Hita y Castillo en el tercer centenario de su nacimiento (1714-2014)", op. cit., pp. 163-184

${ }^{11}$ AMADOR MARRERO, Pablo F.: "Virgen de la Encarnación", en Sacra Memoria. Arte religioso en el Puerto de la Cruz. Puerto de la Cruz: Ayuntamiento, 2001, pp. 100-103. 
los ojos e inclina su cabeza hacia la diestra, en dirección contrapuesta a las manos, que aparecen unidas oracionalmente. Su tipo físico evoca de inmediato el de otras creaciones femeninas de su autor, como la Virgen de la Victoria de la iglesia hispalense del Sagrado Corazón de Jesús, la del Sol de la iglesia mayor de san Mateo de Tarifa (Cádiz) o la de la Candelaria de Gáldar (Gran Canaria), con las que comparte rasgos tan definidos como la frente alta, el trazado de las cejas, la inserción de globos oculares de cristal y unos labios menudos y cerrados que dibujan una tenue sonrisa. También resulta inconfundible la técnica de talla que exhibe su frondosa cabellera, peinada a partir de una raya central y cayendo por la espalda en largos y finos mechones de perfil aristado y discurrir ondulante. El ampuloso manto desciende en diagonal por la espalda de la figura, terciándose por el frente con brioso ímpetu ascendente hasta recogerse sobre el antebrazo izquierdo, al tiempo que el drapeado de sus orillas describe amplios y volados quiebros en algunos de sus tramos. Semejante agitación no llega a descomponer la serena verticalidad que se deriva de su actitud corporal, al describir un cadencioso contraposto meramente insinuado por la flexión y ligero adelanto de su pierna izquierda, quedando los pies ocultos por la túnica, que se derrama sobre la peana de nubes, de la cual sobresalen las puntas de la luna hacia abajo. Las testas aladas de tres querubes se insertan en el frente de este escabel, formando un triángulo invertido; la caracterización de sus caras mofletudas, su vivaracha gestualidad facial y la disposición de sus masas capilares recuerdan al instante las de los ángeles que, en igual número, encontramos a las plantas de la Virgen de los Remedios de la capilla universitaria de Sevilla, amén de los que se asoman en los pedestales de las ya referenciadas Vírgenes de la Victoria y Candelaria. Debe lamentarse el precario estado de conservación en que se expone esta muy apreciable escultura de la Inmaculada, con notorias pérdidas del soporte lígneo que afectan a las falanges superiores de los dedos de las manos y a una parte de los bordes del manto y del flequillo de uno de los angelitos; añádase a lo anterior la existencia de lagunas en su policromía, la presencia de ciertos repintes, la oxidación de los barnices y la suciedad superficial acumulada, para desear su pronta restauración.

El retablo frontero, esto es, el situado en el lado del evangelio del crucero de esta iglesia parroquial de santa María la Blanca, está dedicado a la Virgen del Rosario, una hierática imagen de candelero para vestir que fue titular de una hermandad fundada con toda probabilidad durante el último tercio del siglo XVI, con reglas ratificadas por la autoridad eclesiástica en 1658, existiendo datos que acreditan su existencia al menos hasta 1817 , debiéndose extinguir poco después ${ }^{12}$.

Las cifras de los ingresos que percibían las cofradías radicadas en esta villa señorial de La Campana en 1735 no dejan lugar a dudas a propósito de que la

${ }^{12}$ MIRA CABALLOS, Esteban: La Campana. Noticias históricas, op. cit., pp. 65 y 8789. ROMERO MENSAQUE, Carlos José: El Rosario en la provincia de Sevilla. Religiosidad popular, cofradias y hermandades. Sevilla: Diputación de Sevilla, 2010, p. 82. 
del Rosario era la más potente por entonces, económicamente hablando: 4.785,85 reales anuales, frente a la siguiente, que era la de las Benditas Ánimas del Purgatorio, con $1.421^{13}$. Pues bien, pocos años después, el 6 de octubre de 1742, curiosamente será la fábrica parroquial -y en su nombre el mayordomo Simón Andrade- y no la propia hermandad, la que contrate con el maestro tallista vecino de Sevilla, José de Guillena, la ensambladura del retablo de la Virgen del Rosario, conforme al diseño que éste había presentado, por la suma de 4.475 reales $^{14}$. Se compone de un banco centrado por sagrario, cuerpo de tres calles, la central más ancha y adelantada para acoger el amplio tabernáculo que cobija a la imagen mariana, y un ático bastante desarrollado en altura e igualmente avanzado en su segmento medio ${ }^{15}$. Cuatro afinados estípites de concepción algo pobre sirven para estructurar las calles laterales, y otros dos de menor escala, colocados en esviaje, sostienen el frente del edículo principal. Las hojas rizadas de cardo, los golpes de talla vegetal con presencia puntual de frutas y flores, los fragmentos de frontón curvos y avolutados, la cornisa quebrada y elevada en el centro, constituyen recursos plásticos y decorativos habituales en los retablos de estípites del segundo cuarto del siglo XVIII, marco temporal en que se desarrolló la actividad profesional del entallador José de Guillena, cuya producción documentada -todavía escasa- se inicia en 1723 con el desaparecido retablo del santo Cristo en la parroquia de san Pablo de Aznalcázar, sabiéndose que aún permanecía en activo en 1762, figurando en la relación de tallistas y escultores que declararon la cifra de sus ganancias para efecto de la Única Contribución propuesta por el marqués de la Ensenada ${ }^{16}$.

Volviendo a la escritura notarial de 1742, nos interesa particularmente la apurada reseña que se nos ofrece del conjunto escultórico que allí debía integrarse: "Además de lo que contiene el diseño ha de traer formada arca de sagrario y altar de madera, éste según el que se ha puesto en el retablo de Jesús Nazareno; y han de venir en dicho retablo tres santos: los dos de vara y media y el otro de algo más, éste el patriarca Santo Domingo de Guzmán, para lo alto; otro el Angélico Doctor Santo

${ }^{13}$ MIRA CABALlOS, Esteban: La Campana. Noticias históricas, op. cit., p. 85.

${ }^{14} \mathrm{La}$ fecha de la escritura notarial, junto a un apretado extracto del contrato, fue dado a conocer por HERNÁNDEZ DÍAZ, José; SANCHO CORBACHO, Antonio y COLLANTES DE TERÁN, Francisco: Catálogo arqueológico y artístico de la provincia de Sevilla. Vol. II. Sevilla: Diputación Provincial de Sevilla, 1943, p. 43.

${ }^{15}$ Una breve reseña del retablo la ofrece HERRERA GARCÍA, Francisco Javier: "Conjunto de retablos de estípites de las naves laterales y crucero", en HALCÓN, Fátima; HERRERA, Francisco y RECIO, Álvaro: El retablo barroco sevillano, op. cit., pp. 396397.

${ }^{16}$ Para un conocimiento más extenso de la andadura laboral de este maestro entallador, con la relación completa de sus trabajos documentados hasta el momento, véase RODA PEÑA, José: "José de Guillena y el antiguo retablo mayor de la capilla de san Andrés de Sevilla", en Laboratorio de Arte, n ${ }^{\circ}$ 24, 2012, pp. 354-358. 
Tomás de Aquino, para el lado derecho, y el otro, San Vicente Ferrer, para el siniestro, y además ha de traer dos ángeles vestidos con cornucopias de flores, y sobre el camarín los ángeles como niños, y la urna ha de ser ochavada con tres serafines. $Y$ además ha de traer una tarjeta encima del arco del camarín con la imagen de María Santísima, entregándole el Rosario al Señor Santo Domingo... cuyas figuras han de ser de medio relieve" 17 .

Todo se respetó escrupulosamente y el programa escultórico, de iconografía netamente dominica y rosariana, permanece en los lugares indicados: santo Tomás de Aquino y san Vicente Ferrer en las calles laterales, a derecha e izquierda respectivamente del camarín de la Virgen del Rosario; en la hornacina central del ático, la figura de santo Domingo de Guzmán, escoltada en los extremos del coronamiento por una pareja de ángeles mancebos con cornucopias de flores echados sobre trozos curvos de cornisas; otros dos ángeles niños posados encima de las volutas aveneradas situadas sobre los estípites de la embocadura del tabernáculo mariano; cinco cabezas aladas de serafines distribuidas por la peana tallada de la Virgen -tres-y el banco del retablo - dos-y, por, último la tarjeta o cartela oval con el relieve de la Virgen con el Niño entregando el rosario a santo Domingo que se ubica, en medio de un marco de horajasca, sobre el arco frontal del camarín.

La contemplación detenida de todo este conjunto de imágenes, salvo la de la Virgen del Rosario, que no se cita en el concierto y que indudablemente es de factura algo anterior, nos llevó a la determinación de atribuírselo a Benito de Hita y Castillo, en fecha cercana a la ejecución del retablo, esto es, en torno a 1743. Su filiación estilística y técnica nos parece irrefutable. Señalaremos así, en primer lugar, el parentesco morfológico que apreciamos -en el tratamiento de sus rostros, cabellos y disposición diagonal de sus extremidades anatómicas- entre los dos jóvenes ángeles que en el remate del altar portan los cuernos rebosantes de ramos y flores, respecto a las parejas esculpidas por Hita para diversos retablos mayores: parroquias sevillanas de san Andrés (1738-1739) y san Isidoro (1752), capilla de la Divina Pastora de Cádiz (1753-1754), e incluso aquella otra que tallara en 1763 para el paso procesional del misterio del Desprecio de Herodes, de la cofradía hispalense de la Amargura, y que lamentablemte se destruyó en los disturbios de julio de 1936. Lo mismo podría argüirse respecto a los dos rozagantes angelitos casi desnudos que describíamos cabalgando sobre los estípites centrales del camarín, tan similares a los muchos que pululan por otras estructuras arquitectónicas en madera en las que Hita intervino como escultor -a título de mero ejemplo, citaré los que figuran en los extremos del ático del retablo de la Virgen de los Remedios, en la capilla de la Universidad hispalense (1762-1763)-, o a los volanderos que forman parte del acompañamiento de algunas de sus efigies marianas, como

${ }^{17}$ HERNÁNDEZ DÍAZ, José; SANCHO CORBACHO, Antonio y COLLANTES DE TERÁN, Francisco: Catálogo arqueológico y artístico de la provincia de Sevilla. Vol. II, op. cit., p. 43. 
la Reina de los Ángeles de la parroquia del Rosario de Cádiz (1743) o la Inmaculada de la capilla sacramental del templo sevillano de santa Catalina (1752-1753). Análogas cabezas aladas de querubes, que en este retablo aparecen en número de cinco, las encontramos repartidas con esta misma orientación frontal en otros varios altares donde Hita colaboró con sus esculturas y relieves, así como, con mayor variedad de direcciones, en varias de las peanas de sus Vírgenes.

Del relieve de la entrega del rosario a santo Domingo de Guzmán no cabe sino reconocer su modesta resolución plástica, justificable en razón de la altura a la que debe ser contemplado, sirviendo de enlace entre la titular del retablo, la Virgen del Rosario, y la talla del fundador de la Orden de Predicadores (11701221) que se alza en el nicho central del coronamiento. Esta última tiene el interés suplementario de ser la única representación exenta que de santo Domingo nos ha llegado de manos de Hita, al menos que conozcamos hasta ahora, no apartándose del arquetípico patrón -barroquizado en el giro de su cabeza y el movimiento de los paños que componen el dominico hábito albinegro- que nos lo presenta sosteniendo en alto la banderola con su mano derecha, al tiempo que con la contraria sujeta y estrecha contra su cadera un libro.

Por su parte, la escultura de santo Tomás de Aquino está muy relacionada, a nivel formal e iconográfico, con la que, pocos años después, habría de plasmar para el retablo mayor de la capilla sacramental de santa Catalina de Sevilla (17481753), aunque son igualmente visibles algunos distingos en su composición. En ambos casos, el santo de Aquino (1225-1274), proclamado doctor de la Iglesia por san Pío V en 1567 como eminente filósofo y teólogo que fue, ostenta un birrete sobre su cabeza, exhibe en el centro de la esclavina la cadena áurea con el sol radiado que proclama el carácter sobrenatural de su doctrina, alza una pluma -desaparecida- en su diestra y sostiene un libro abierto en la palma de la mano izquierda, que en el de La Campana se complementa con una maqueta de templo sobre sus páginas, pues también es un atributo de su categoría doctoral; en cambio, el de la capilla sacramental hispalense posee unas alas que aluden a su condición de "Doctor Angélico" -por sus cualidades de inteligencia, sabiduría y pureza-, que no tiene el ejemplo que nos ocupa ${ }^{18}$. Su acendrada devoción mariana, ensalzada en sus escritos, explica de sobra que las dos tallas levanten y giren sus rostros hacia la izquierda, para mirar directamente hacia las imágenes de la Virgen que presiden estos retablos: aquí la del Rosario y la Inmaculada en el del recinto eucarístico.

En clara correspondencia con la anterior, se yergue en la calle lateral contraria la efigie del valenciano san Vicente Ferrer (1350-1419), confesor de Benedicto XIII y consejero de monarcas, nobles y regidores municipales. Como signo

${ }_{18}$ Para profundizar en todos estos aspectos, resulta recomendable la lectura del artículo de PÉREZ SANTAMARÍA, Aurora: "Aproximación a la iconografía y simbología de santo Tomás de Aquino", en Cuadernos de Arte e Iconografía, n 5, 1990, pp. 31-54. 
de su pertenencia a la Orden de santo Domingo, viste su característico hábito, y en la cabeza muestra la tonsura indicativa de su consagración en el estado clerical. Ha perdido la pluma que llevaba en su elevada mano derecha, portando en la izquierda un libro cerrado, atributo de su ardiente predicación, a través de la cual llamó a la conversión y al seguimiento de Cristo ${ }^{19}$. La dispar posición de los brazos, configurando una diagonal que encuentra su réplica en la caída del largo escapulario, así como la elegante manera de recoger la punta del manto bajo el brazo izquierdo, resta estatismo a las figuras de estos dos últimos santos dominicos, volviendo también san Vicente Ferrer su rostro hacia la Virgen, pero de un modo menos pronunciado del que observábamos en santo Tomás de Aquino. Digamos, en fin, que los semblantes imberbes de uno y otro, en los que aflora una expresión de contenida emoción, responden a una modalidad fisonómica habitualmente empleada por Hita y Castillo en parte de su repertorio hagiográfico.

Como demostrara en su momento Mira Caballos, el dorado de este retablo de Nuestra Señora del Rosario, así como la policromía y estofado de sus esculturas, no se acometió hasta veinte años después de haberse concertado su talla. En esta ocasión, sí fue la cofradía rosariana, a través de su mayordoma Isabel Arias, la que contrató esta tarea con José Valdés, maestro dorador vecino de Carmona y residente en La Campana, el 2 de marzo de 1763, quien se comprometió a verificarla en el término de ocho meses y por un precio de 9.200 reale $^{20}$. Se entiende así que la rocalla haga su aparición en las fimbrias de los ropajes que visten los santos dominicos estudiados. Este José Valdés, o alguno de sus operarios, debió de ser quien pintara las pequeñas quince cartelas de formato mixtilíneo con los misterios del santo rosario, hoy apenas visibles por el absoluto oscurecimiento de las escenas y su irregular distribución por el banco (dos) y el ático (trece) del retablo ${ }^{21}$.

Fecha de recepción: 3 de septiembre de 2014

Fecha de aceptación: 28 de noviembre de 2014

${ }^{19}$ RÉAU, Louis: Iconografía del arte cristiano. Iconografía de los santos, P-Z. Barcelona: Serbal, 1998, pp. 328-331.

${ }^{20}$ El documento notarial está íntegramente publicado por MIRA CABALLOS, Esteban: La Campana. Noticias históricas, op. cit., pp. 125-126.

${ }^{21}$ HERRERA GARCÍA, Francisco Javier: "Retablos Rosario: ¿tipología retablística o modalidad iconográfica?", en Congreso Internacional del Rosario. Actas. Sevilla: Área de Fiestas Mayores del Ayuntamiento de Sevilla, 2004, p. 577. 


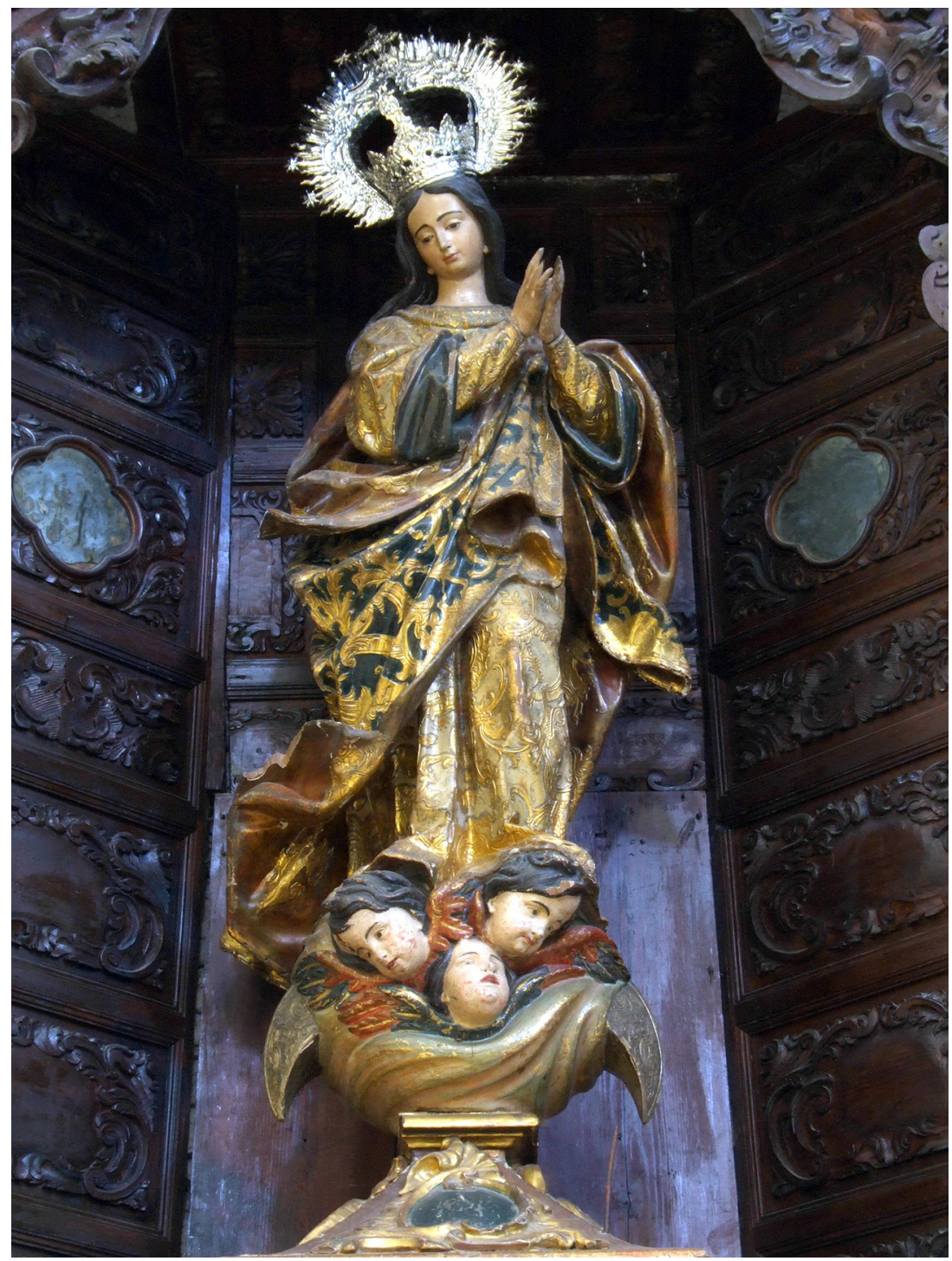

Figura 1. Benito de Hita y Castillo. Inmaculada Concepción. Parroquia de Santa María la Blanca, La Campana (Sevilla). 


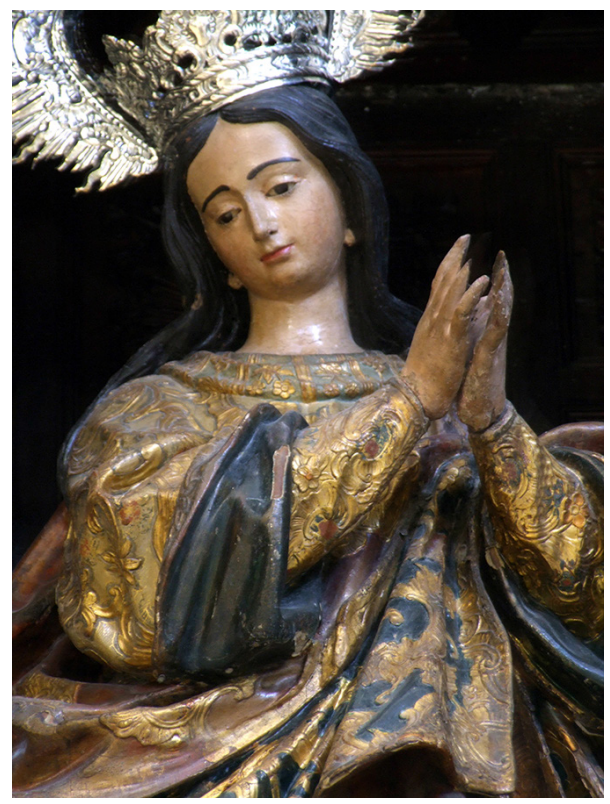

Figura 2. Benito de Hita y Castillo. Inmaculada Concepción (detalle). Parroquia de Santa María la Blanca, La Campana (Sevilla).

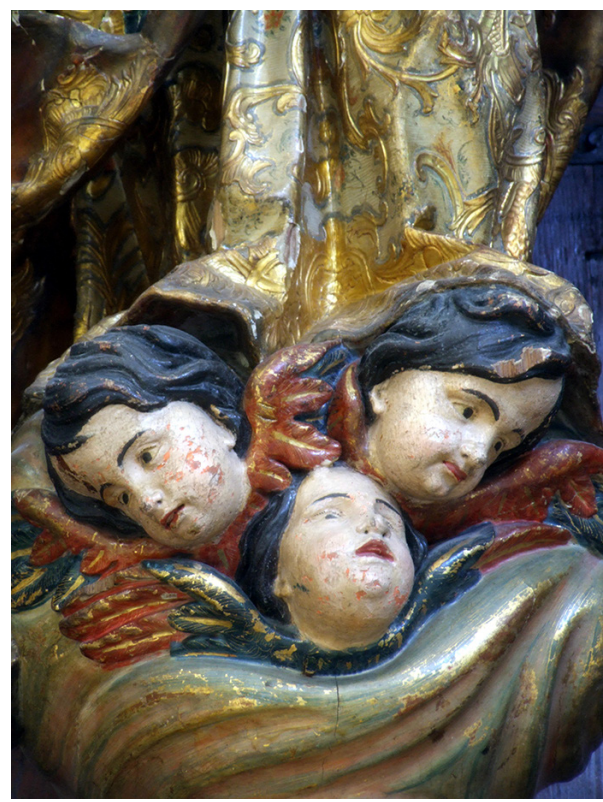

Figura 3. Benito de Hita y Castillo. Inmaculada Concepción (detalle). Parroquia de Santa María la Blanca, La Campana (Sevilla). 


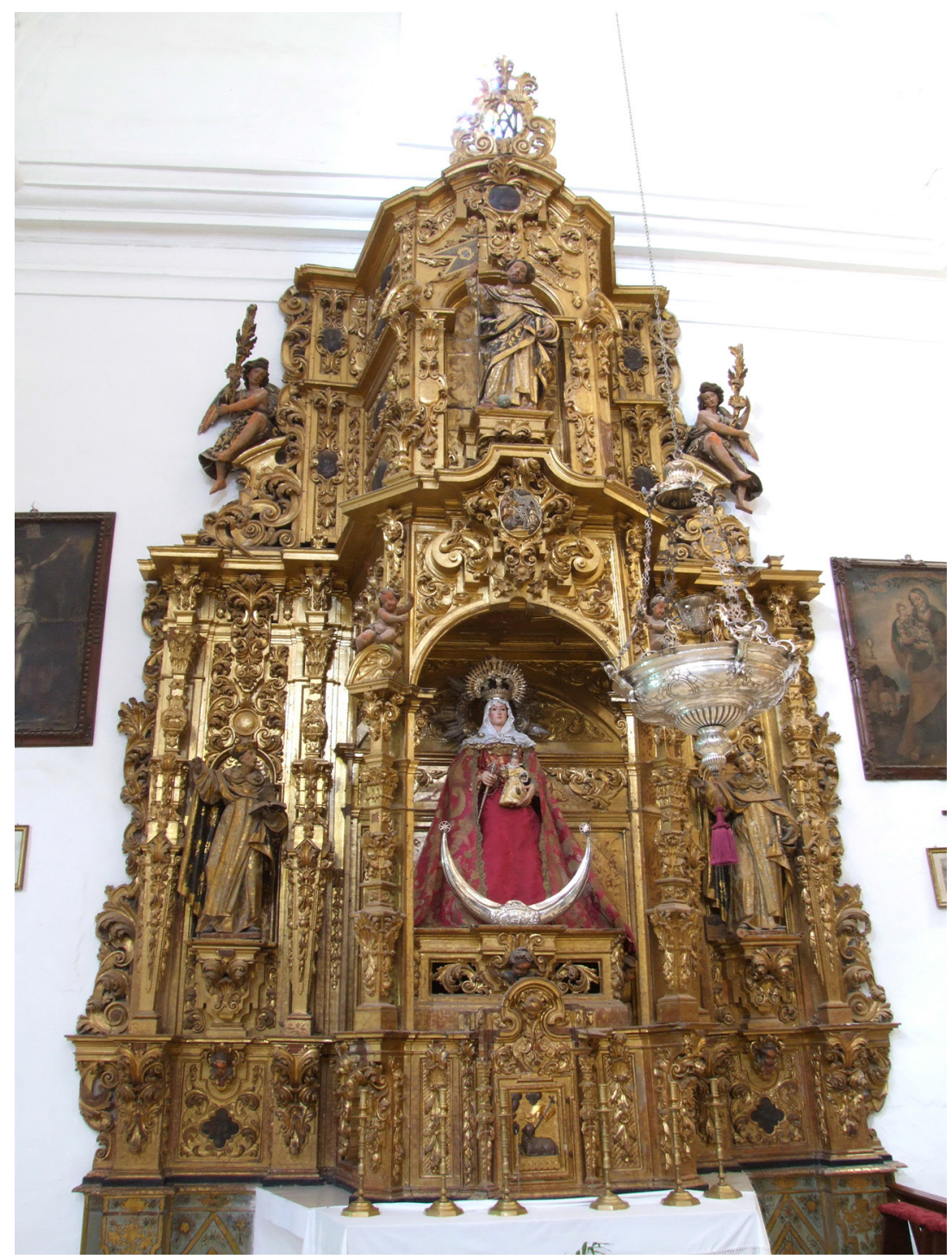

Figura 4. José de Guillena. Retablo de la Virgen del Rosario. 1742-1743. Parroquia de Santa María la Blanca, La Campana (Sevilla). 


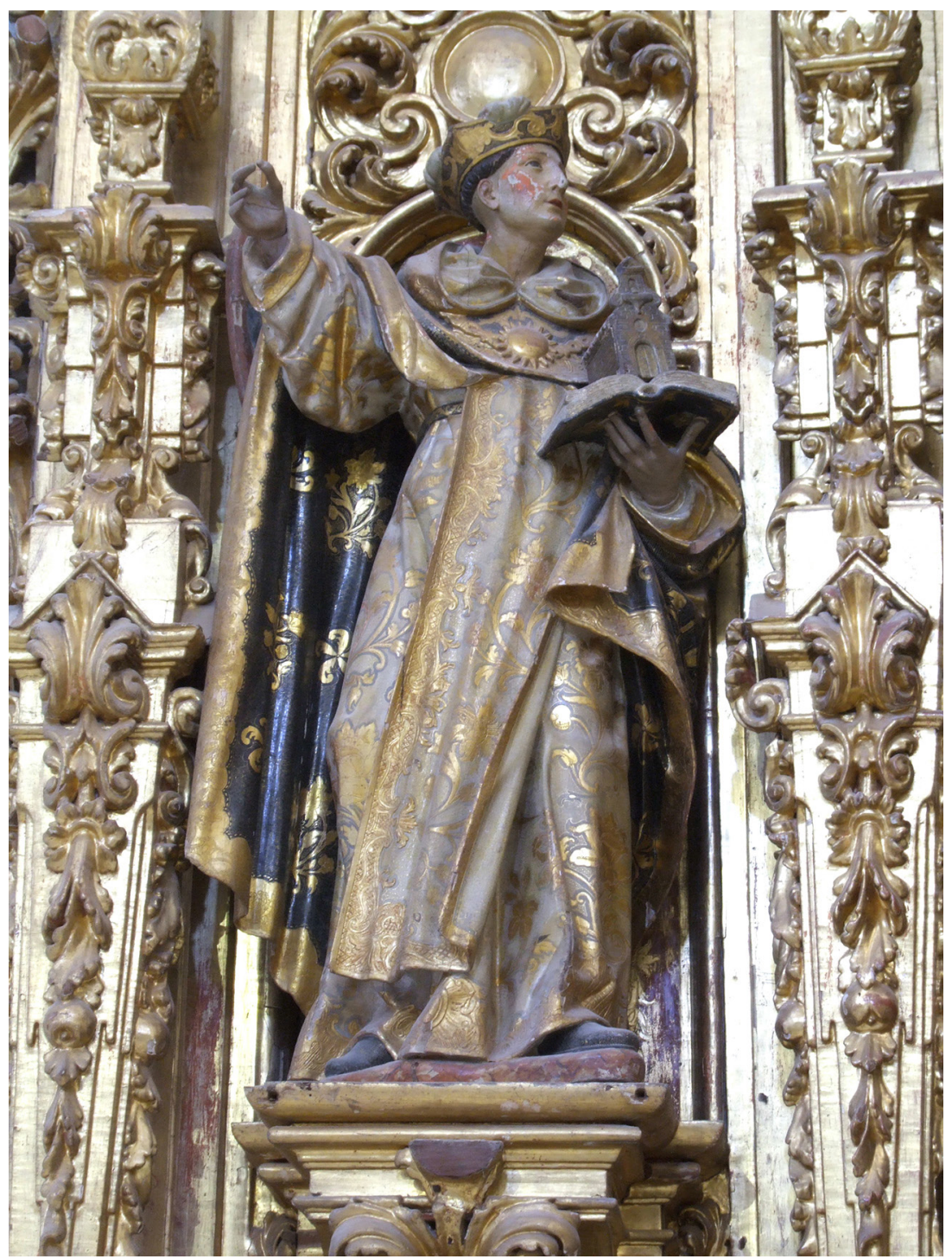

Figura 5. Benito de Hita y Castillo. Santo Tomás de Aquino. Parroquia de Santa María la Blanca, La Campana (Sevilla). 


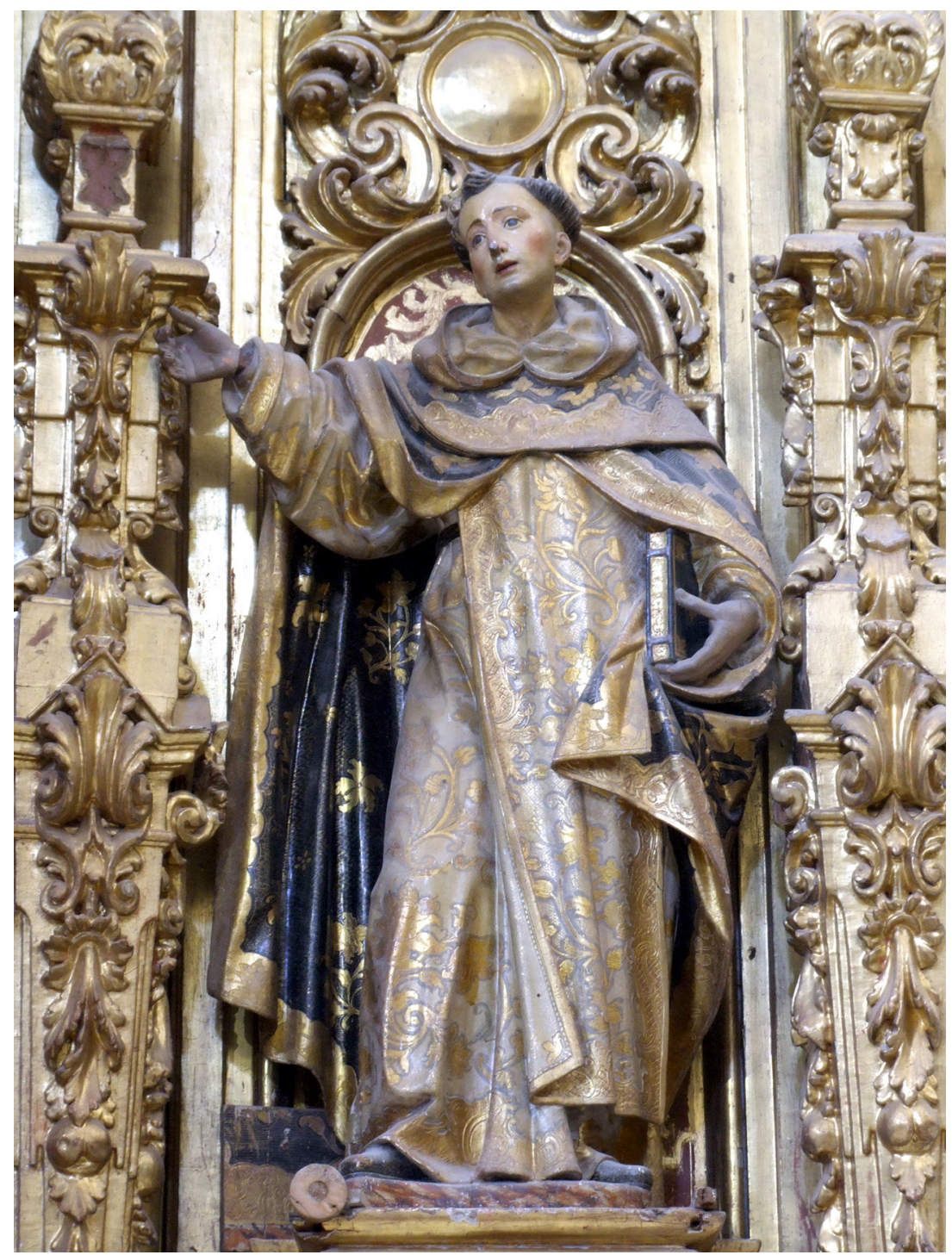

Figura 6. Benito de Hita y Castillo. San Vicente Ferrer. Parroquia de Santa María la Blanca, La Campana (Sevilla). 


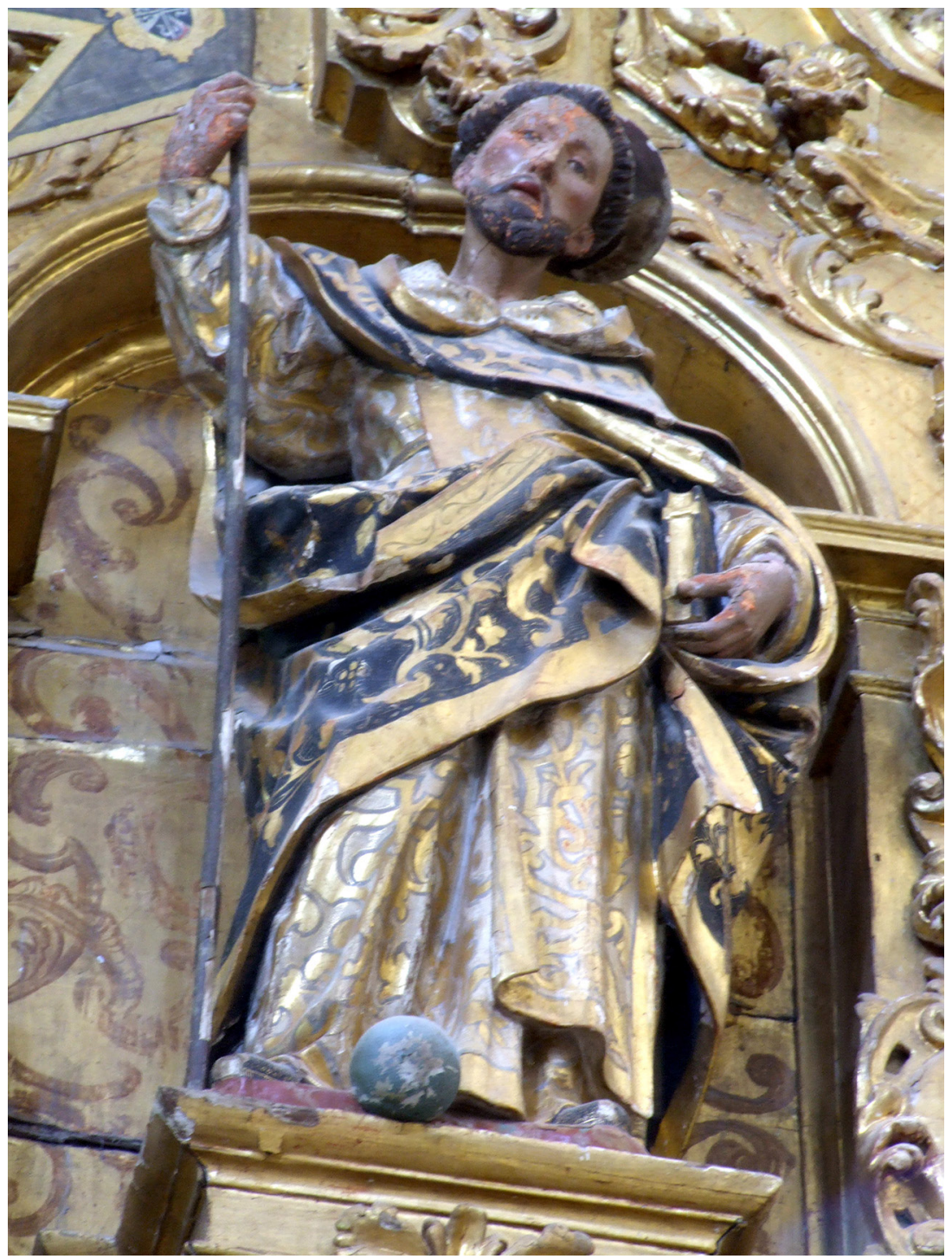

Figura 7. Benito de Hita y Castillo. Santo Domingo de Guzmán. Parroquia de Santa María la Blanca, La Campana (Sevilla). 
Figura 8. Benito de Hita y Castillo. Virgen con el Niño entregando el rosario a santo Domingo. Parroquia de Santa María la Blanca, La Campana (Sevilla).

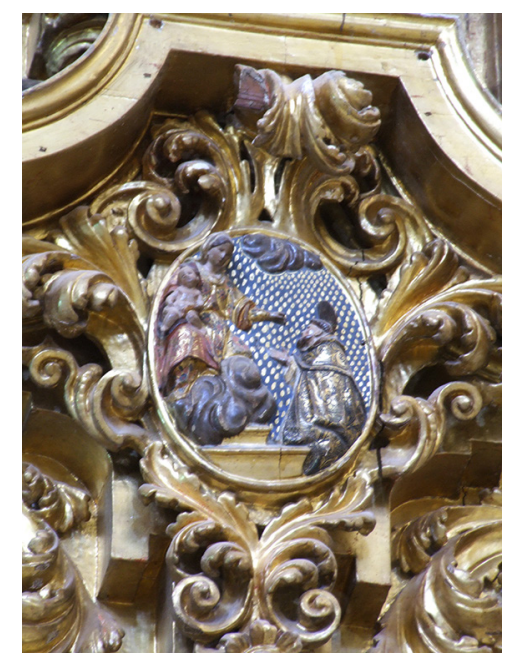

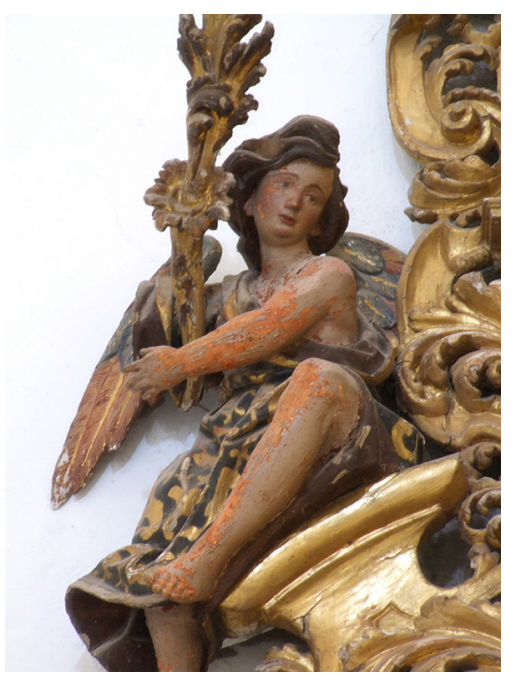

Figura 9. Benito de Hita y Castillo. Ángel con cornucopia de flores.

Parroquia de Santa María la Blanca, La Campana (Sevilla).

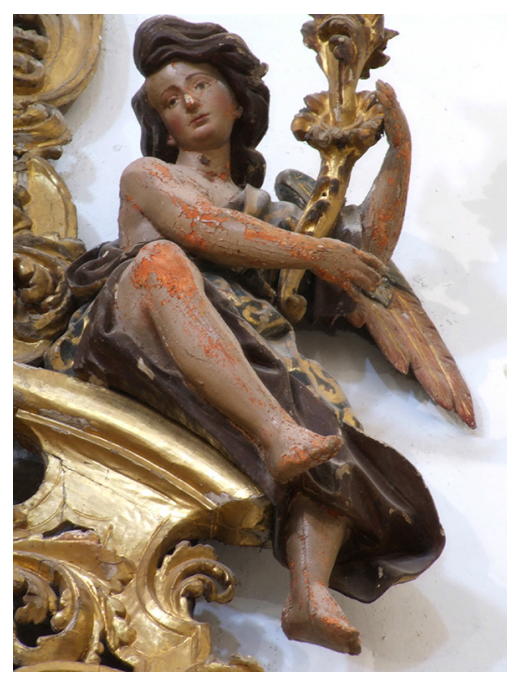

Figura 10. Benito de Hita y Castillo. Ángel con cornucopia de flores.

Parroquia de Santa María la Blanca, La Campana (Sevilla). 